\title{
Effect of Water Cement Ratio in Hybrid Fibre Reinforced Concrete
}

\author{
Thendral Sundararajan, Arunya.A,Chitra.R
}

\begin{abstract}
This paper presents to consider quality and exhibitions of steel fiber fortified cement (SFRC) and half and half fiber strengthened cement (HFRC) distinctive water concrete proportion just as $0.4,0.35$. The half breed filaments consider in the mix of snared end steel strands and polypropylenes filaments. Technique: To think about the compressive quality in the fiber content measurement $V f$ ran from 0.5 to 2.0 percent of steel filaments, and 0.8SF0.2PP, $0.7 S F 0.3 P P, 0.6 S F 0.4 P P, 0.5 S F 0.5 P P$ of half breed strands for two diverse water bond proportion, the evaluation of cement utilized for this examination M40. Totally16 blends were arranged and tried in the lab. Results: at long last, $1.0 \%$ of SFRC and 0.8SF 0.2 PP HFRC gives great quality for both water bond proportion Less quantities of splits were seen in fiber fortified high quality solid examples, which demonstrate an improved malleability with the expansion of strands in the framework.
\end{abstract}

\section{KeyWords: Fibre Reinforced Concrete, SFRC}

\section{INTRODUCTION}

Fragile materials are considered to have no huge post-splitting pliability. Sinewy composites have been and are being created to give improved mechanical properties and sturdiness to generally weak materials. At the point when exposed to pressure, these unreinforced fragile grids at first twist flexibly. The versatile reaction is trailed by small scale splitting, restricted large scale breaking, lastly cracks. Probably the best advantage to be picked up by utilizing fiber support is improved long haul workableness of the structure or itemVanquish impairment of lower handiness caused in view of usage of simply more elevated amount of steel fibers. Potential piece of breathing space in improving strong properties similarly as diminishing the general cost of strong age. An examination on the mechanical show of Hybrid fiber Reinforced Concrete (HFRC). [2] They are used in different degrees as $0.25 \%, 0.5 \%, 0.75 \%$, and $1 \%$ in this examination. [14],[ 16], [18]

\section{MATERIALS AND MIX PROPORTIONS}

\section{A. Materials}

B. The bond utilized in solid blends was common Portland concrete of 43 grades, fine total was regular waterway sand affirming to Zone II of IS 383:1970 with most extreme size of under 4.75. Coarse total fulfills degree in Table 2 of IS 383:1970. The properties of super plasticizer are given in table 1. Two kinds of filaments were utilized for present examination (I) Hooked steel strands 50mm long and (ii) Polypropylene filaments. The properties of snared steel fiber and polypropylene filaments are given in Table 2 and Table 3 individually[1],[3],[5]

\section{B. Mix Proportions}

After the nitty gritty exploratory examination of various quality parameters has been done, the accompanying outcomes have been found. to contemplate quality and exhibitions of SFRC and HFRC distinctive water bond proportion just as 0.4 and 0.35 for preliminary blend compressive quality fiber content dose went from 0.5 to 2.0 of SFRC and $0.7 \mathrm{SF} \quad 0.3 \mathrm{PP}, 0.6 \mathrm{SF} \quad 0.4 \mathrm{PP}, 0.5 \mathrm{SF} \quad 0.5 \mathrm{PP}$ HFRC cast in the 7 days compressive quality it gives great compressive quality of $1 \%$ SFRC $0.8 \mathrm{SF} 0.2 \mathrm{PP}$ HFRC for further cast examples utilized $1 \%$ SFRC and 0.8 SF0.2PP HFRC to test on compressive quality split rigidity, Modulus of break, the usefulness of new cement by utilizing $0.8 \%$ super plasticizer all through blend, the functionality of crossover fiber strengthened cement for both W/C proportion gets progressively diminished to look at SFRC and furthermore 0.35 water bond proportion for both cement SFRC, HFRC can be decreased to think about the $0.4 \%$ water bond proportion, the quality of SFRC with water concrete proportion is the principle factor affecting the quality of SFRC and HFRC the quality of SFRC with W/C Ratio is conversely relative to increment, yet in the HFRC it gives less solidarity solidarity to analyze the 0.4 water bond proportion [7],[9],[11] 
Table -1 Strength Details

\begin{tabular}{|c|c|c|c|c|c|c|c|c|}
\hline $\begin{array}{c}\text { Percentage } \\
\text { of fibres }\end{array}$ & $\begin{array}{l}\text { w/C } \\
\text { Ratio }\end{array}$ & $\begin{array}{c}\text { Types of } \\
\text { concrete }\end{array}$ & $\begin{array}{c}\text { Compressive } \\
\text { Strength } \\
\left.(\mathrm{N} / \mathrm{mm})^{\prime}\right)\end{array}$ & $\begin{array}{c}\text { Increased } \\
\text { strength } \\
\text { (9.6) }\end{array}$ & $\begin{array}{c}\begin{array}{c}\text { Spilt } \\
\text { tensile } \\
\text { strength } \\
\left(\mathrm{N} / \mathrm{mm}^{2}\right)\end{array}\end{array}$ & $\begin{array}{c}\text { Increased } \\
\text { strength } \\
\text { (96) }\end{array}$ & $\begin{array}{c}\text { Modulus } \\
\text { of } \\
\text { rupture } \\
(\mathrm{N} / \mathrm{mm})\end{array}$ & $\begin{array}{c}\begin{array}{c}\text { Increased } \\
\text { strength } \\
(96)\end{array} \\
(96)\end{array}$ \\
\hline \multirow{4}{*}{1.0} & \multirow{2}{*}{0.4} & $\begin{array}{l}\text { Steel fibres } \\
\text { (SF100 PP0) }\end{array}$ & 51.68 & 22.37 & 4.20 & 14.23 & 6.32 & 32.48 \\
\hline & & $\begin{array}{l}\text { Hybrid fibres } \\
\text { (SF80PP30) }\end{array}$ & 62.52 & 27.07 & 4.34 & 14.71 & 7.85 & 40.34 \\
\hline & \multirow{2}{*}{0.35} & $\begin{array}{c}\text { Steel fibres } \\
\text { (SF100 PP0) }\end{array}$ & 55.85 & 24.16 & 4.62 & 15.66 & 6.91 & 35.51 \\
\hline & & $\begin{array}{l}\text { Hybrid fibres } \\
\text { (SF80PP30) }\end{array}$ & 45.58 & 19.60 & 3.69 & 12.50 & 6.25 & 32.12 \\
\hline
\end{tabular}

\section{CONCLUSION}

The accompanying end could be drawn from the examination it is seen that compressive, split rigidity and flexural quality are on HFRC higher as for SFRC in the water bond apportion 0.4 and furthermore It is seen that compressive quality, split elasticity and flexural quality are on HYFR is lesser than concerning SFRC in the water bond proportion 0.35 Less quantities of breaks were seen in fiber strengthened high quality solid examples, which demonstrate an improved pliability with the expansion of filaments in the network

\section{REFERENCES}

1. Iyappan L., Dayakar P., Identification of landslide prone zone for coonoortalukusing spatial technology, International Journal of Applied Engineering Research,V-9,I-22,PP-5724-5732,Y-2014.

2. Kumar J., Sathish Kumar K., Dayakar P.,Effect of microsilica on high strength concrete, International Journal of Applied Engineering Research,V-9,I-22,PP-5427-5432,Y-2014.

3. Dayakar P., Vijay Ruthrapathi G., Prakesh J., Management of bio-medical waste, International Journal of Applied Engineering Research,V-9,I-22,PP-5518-5526,Y-2014.

4. Swaminathan N., Dayakar P., Resource optimization in construction project, International Journal of Applied Engineering Research,V-9,I-22,PP-5546-5551,Y-2014.

5. Venkat Raman K., Dayakar P., Raju K.V.B.,An experimental study on effect of cone diameters in penetration test on sandy soil, International Journal of Civil Engineering and Technology,V-8,I-8,PP-1581-1588,Y-2017.

6. Saritha B., Chockalingam M.P.,Photodradation of malachite green DYE using TIO2/activated carbon composite,International Journal of Civil Engineering and Technology,V-8,I-8,PP-156-163,Y-2017

7. Shendge R.B., Chockalingam M.P., Saritha B., Ambica A.,Swat modelling for sediment yield: A case study of Ujjani reservoir in Maharashtra, India,International Journal of Civil Engineering and Technology,V-9,I-1,PP-245-252,Y-2018

8. Chockalingam M.P., Balamurgan V.,Modernisation of an existing urban road-sector in Chennai, a case study report,International Journal of Civil Engineering and Technology,V-8,I-8,PP-1457-1467,Y-2017

9. Saritha B., Chockalingam M.P.,Adsorption study on removal of basic dye by modified coconut shell adsorbent, International Journal of Civil Engineering and Technology,V-8,I-8,PP-1370-1374,Y-2017

10. Saritha B., Chockalingam M.P.,Adsorptive removal of heavy metal chromium from aqueous medium using modified natural adsorbent,International Journal of Civil Engineering and Technology,V-8,I-8,PP-1382-1387,Y-2017

11. Chockalingam M.P., Palanivelraja S.,Retrospective analysis of a theoretical model used for forecasting future air quality near the north Chennai thermal power plant,International Journal of Civil Engineering and Technology,V-8,I-8,PP-1457-1467,Y-2017

12. Saritha B., Chockalingam M.P.,Photodegradation of methylene blue dye in aqueous medium by $\mathrm{Fe}-\mathrm{AC} / \mathrm{TiO} 2$ Composite,Nature Environment and Pollution Technology,V-17,I-4,PP-1259-1265,Y-2018

13. Shendge R.B., Chockalingam M.P., Kaviya B., Ambica A.,Estimates of potential evapotranspiration rates by three methods in upper Bhima Basin, In Maharashtra, India,International Journal of Civil Engineering and Technology,V-9,I-2,PP-475-480,Y-2018
14. Shendge R.B., Chockalingam M.P.,The soil and water assessment tool for Ujjani Reservoir,International Journal of Mechanical Engineering and Technology,V-9,I-2,PP-354-359,Y-2018

15. Shendge R.B., Chockalingam M.P.,A review on soil and water assessment tool,International Journal of Mechanical Engineering and Technology,V-9,I-2,PP-347-353,Y-2018

16. Sachithanandam P., Meikandaan T.P., Srividya T.,Steel framed multi storey residential building analysis and design,International Journal of Applied Engineering Research,V-9,I-22,PP-5527-5529,Y-2014

17. Meikandaan T.P., Ramachandra Murthy A.,Study of damaged RC beams repaired by bonding of CFRP laminates,International Journal of Civil Engineering and Technology,V-8,I-2,PP-470-486,Y-2017

18. Meikandaan T.P., Ramachandra Murthy A.,Retrofittng of reinforced concrete beams using GFRP overlays,International Journal of Civil Engineering and Technology,V-8,I-2,PP-423-439,Y-2017

19. Meikandaan T.P., Ramachandra Murthy A.,Flexural behaviour of RC beam wrapped with GFRP sheets,International Journal of Civil Engineering and Technology,V-8,I-2,PP-452-469,Y-2017

20. Meikandaan T.P., Murthy A.R.,Experimental study on strengthening of rc beams using glass Fiber,International Journal of Civil Engineering and Technology,V-9,I-11,PP-959-965,Y-2018

21. Meikandaan T.P., Hemapriya M.,Use of glass FRP sheets as external flexural reinforcement in RCC Beam,International Journal of Civil Engineering and Technology,V-8,I-8,PP-1485-1501,Y-2017

22. Saraswathy R., Saritha B.,Planning of integrated satellite township at Thirumazhisai,International Journal of Applied Engineering Research,V-9,I-22,PP-5558-5560,Y-2014

23. Saritha B., Ilayaraja K., Eqyaabal Z., Geo textiles and geo synthetics for soil reinforcement,International Journal of Applied Engineering Research,V-9,I-22,PP-5533-5536,Y-2014

24. Ambica A., Saritha B., Changring G., Singh N B., Rajen M., Salman Md.,Analysis of groundwater quality in and around Tambaram taluk, Kancheepuram district,International Journal of Civil Engineering and Technology,V-8,I-8,PP-1362-1369,Y-2017

25. Arunya A., Sarayu K., Ramachandra Murthy A., Iyer N.R.,Enhancement of durability properties of bioconcrete incorporated with nano silica,International Journal of Civil Engineering and Technology,V-8,I-8,PP-1388-1394,Y-2017

26. Ilayaraja K., Krishnamurthy R.R., Jayaprakash M., Velmurugan P.M., Muthuraj S.,Characterization of the 26 December 2004 tsunami deposits in Andaman Islands (Bay of Bengal, India),Environmental Earth Sciences, V-66,I-8,PP-2459-2476,Y-2012

27. Ilayaraja K.,Morphometric parameters of micro watershed in Paravanar sub-basin, Cuddalore District,International Journal of Civil Engineering and Technology,V-8,I-8,PP-1444-1449,Y-2017

28. Ilayaraja K., Singh R.K., Rana N., Chauhan R., Sutradhar N.,Site suitability assessment for residential areas in south Chennai region using remote sensing and GIS techniques, International Journal of Civil Engineering and Technology,V-8,I-8,PP-1468-1475,Y-2017

29. Ilayaraja K., Reza W., Kumar V., Paul S., Chowdhary R.,Estimation of land surface temperature of Chennai metropolitan area using Landsat images,International Journal of Civil Engineering and Technology,V-8,I-8,PP-1450-1456,Y-2017

30. Chitra R.,Experimental study on beam using steel fiber and latex,International Journal of Civil Engineering and Technology,V-8,I-8,PP-1395-1403,Y-2017

31. Chitra R.,Analysis of traffic and management at Kovilambakkam intersection,International Journal of Civil Engineering and Technology,V-8,I-8,PP-1433-1443,Y-2017

32. Aswathy M.,Experimental study on light weight foamed concrete,International Journal of Civil Engineering and Technology,V-8,I-8,PP-1404-1412,Y-2017

33. Aswathy M.,Wastewater treatment using constructed wetland with water lettuce (Eichornia Crasipies),International Journal of Civil Engineering and Technology,V-8,I-8,PP-1413-1421,Y-2017

34. Kiruthiga K., Anandh K.S., Gunasekaran K, Assessment of influencing factors on improving effectiveness and productivity of construction engineers, 2015, International Journal of Applied Engineering Research, V $-10, \mathrm{I}-17, \mathrm{p}-13849-13854$. 


\section{AUTHORS PROFILE}

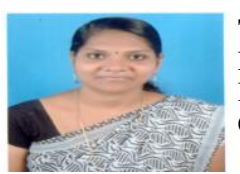

Thendral Sundarrajan, Assistant Professor, Department of Computer Science \& Engineering,

Bharath Institute of Higher Education and Research,

Chennai, India

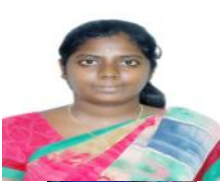

A.Arunya, Associate Professor, Department of Computer Science \& Engineering, Bharath Institute of Higher Education and Research, Chennai, India

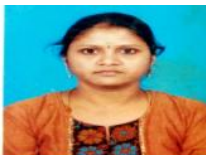

R.Chitra, Assistant Professor, Department of Computer Science \& Engineering, Bharath Institute of Higher Education and Research, Chennai, India 